\title{
RETHINKING WORKFORCE DIVERSITY RESEARCH THROUGH CRITICAL PERSPECTIVES: EMERGING PATTERNS AND RESEARCH AGENDA ${ }^{1}$
}

Dr. Erhan AYDIN ${ }^{2}$

Dr. Emir OZEREN ${ }^{3}$
Received (Submission Date): 01/11/2018

Accepted (Acception Date): 15/11/2018

Published Date (Yayın Tarihi): 30/11/2018

\section{ABSTRACT}

This paper aims at highlighting the theoretical development of diversity management by providing an integrated understanding of how diversity management has made progress and evolved in organisations. The current article adopts a conceptual and critical review to demonstrate the changes and shifts in diversity management research. This study reveals that there are four stages of workforce diversity within the business and management field. These stages are equal employment opportunity/affirmative action, valuing differences, diversity management and global diversity management. Each stage is discussed in greater details within the article. This study contributes to the broader diversity management literature in three main ways: firstly, by shedding some light on the conceptual clarity of the diversity notion itself; secondly, by foregrounding the holistic view of diversity management; thirdly, by reflecting the recent developments in diversity research. The review consistently points to the fact that the current literature on diversity management has been predominantly shaped by a mainstream managerial discourse and neoliberal logic which has mostly a discrimination focus rather than an inclusiveness perspective. The paper also suggests that further research is required on workforce diversity particularly with an emic, an intersectional, a contextual and a relational approach rather than reproducing the existing knowledge by an etic framing of diversity from an instrumental point of view that dominates the extant literature.

Keywords: Equality, Inclusion/Inclusiveness, Discrimination, Workforce Diversity, Diversity Management, Diversity Research, Intersectionality, Critical Management Studies, Emic, Relational Approach

Jel Codes: B10, M10, M54

\section{ELEŞTİREL BAKIŞ AÇISI İLE İ̧̧GÜCÜ FARKLILIĞI ARAŞTIRMALARININ YENIDEN DEĞERLENDİRILMESİ: ORTAYA ÇIKAN ÖRÜNTÜLER VE ARAŞTIRMA GÜNDEMI}

ÖZ

Bu çalışma, farklllık yönetiminin örgütlerde nasıl ilerlediğini ve geliştiğini bütünleştirerek farklılık yönetimi yazınının kuramsal gelişimine dikkat çekmeyi amaçlamaktadır. Makale, farklılık yönetimi

\footnotetext{
${ }^{1}$ This paper is the final version of the work which has been significantly improved and extended after being presented at the International Business and Organization Research (BOR) Conference in Safranbolu between 12 -14 September 2018

${ }^{2}$ Usak University, Turkey, (Affiliate Research Fellow, IPAG Business School Paris, France); erhanaydin.phd@gmail.com and e.aydin@ipag.fr https://orcid.org/0000-0003-2530-9058

3 Dokuz Eylül University, Reha Midilli Foca Faculty of Tourism, Turkey, emir.ozeren@deu.edu.tr and emirozeren@yahoo.com https://orcid.org/0000-0002-4219-8401
}

Business \& Management Studies: An International Journal Vol.:6 Issue:3 Year:2018, pp. 650-670 
araştırmalarındaki değişimleri ve dönüşümleri göstermek üzere kavramsal ve eleştirel bir incelemeyi benimsemektedir. Çalışma, işletme ve yönetim alanındaki işgücü farklllıklarının dört aşamasının olduğunu ortaya koymaktadır. Bu aşamalar, eşit istihdam olanakları/pozitif ayrımcılık, farklılıklara değer vermek, farklılıkların yönetimi ve küresel farklılıkların yönetimidir. Makalede her aşama ayrıntılı bir şekilde ele alınmıştır. Bu araştırma, farklılık yönetimi yazınına üç temel yolla katkıda bulunmaktadır: Birincisi, 'farklılık' nosyonuna kavramsal açıdan netlik kazandırmak; ikincisi, farklılık yönetimine dair bütüncül bakış açısını öne çıkarmak; üçüncüsü ise farklılık araştırmalarına ilişkin güncel gelişmeleri, eğilimleri yansıtmaktır. Bu inceleme, farklılık yönetimi yazınının ă̆ırlıklı olarak anaakım yönetsel söylem ve neoliberal mantıkla şekillendiğini, yazınının kapsayıcı bakış açısındansa çoğunlukla ayrımcılık sorunsalını odağına alan çalışmalarla ilerlediğini vurgulamaktadır. Ayrıca, söz konusu çalışma, mevcut yazına egemen araçsal bakış açısıyla bilgiyi etik yaklaşımla yeniden üreten anlayışın yerine, gelecek araştırmaların özellikle emik yaklaşımla işgücü farklılıklarının kesişimsel, bağlamsal ve ilişkisel yönlerini ortaya çıkaracak bir bakıç açısıyla kurgulanmaları gerektiğini önermektedir.

Anahtar Kelimeler: Eşitlik, Farklılık, Kapsayıcı/Kapsayıcılık, Ayrımcılık, Işgücü Çeşitliliği, Farklılıkların Yönetimi, Farklılık Araştırmaları, Kesişimsellik, Eleştirel Yönetim Çalışmaları, Emik, Ilişkisel Yaklaşım

Jel Kodlart: B10, M10, M54

\section{INTRODUCTION}

Today's workforce reflects the heterogeneity of employee characteristics in terms of sex, race, ethnicity, disability, belief or religion, age, sexual orientation and gender identity throughout the world. Equality, diversity and inclusion in the workplace have a long tradition of struggles on gaining equal rights, civil rights movement, recognition of basic rights and freedom not only to privileged classes but also to historically marginalised groups and excluded communities. The demographic trends in the workforce, increasing pace of globalisation, growing demands by minorities to become more visible at work, raising awareness on gender equality along with the feminist movement worldwide have resulted in central debates on diversity which tends to shift away from merely legal and moral consideration towards more strategic issues for organisations (Jonsen et al., 2011).

Diversity management (hereafter DM) rests on the mainstream management idea that managing diversity in a workplace will enhance organizational performance. Organizations that can manage diversity in line with their overall objectives may broaden their customer base and employee candidate pool, thereby gaining a competitive advantage. In other words, the diverse characteristics of employees will be taken into account as long as they serve the purposes of the organization which are directly linked to the managerial interests. This implies that diversity that is considered to have no significant contribution to the organization's bottom line can be ignored and excluded. For instance, the recognition and visibility of LGBTI (lesbian, gay, bisexual, transgender, intersex) employees can be neglected and they can be even marginalized in work settings where male-dominant values, 
homophobia prevail and heteronormative structure is widely accepted. Consistent with this view, Ahonen et al., (2014) challenged the mainstream framing of diversity for reproducing organizational contexts where white heterosexual middle-class men are becoming a norm and where others are viewed as "different" and to be managed. Thus, the studying workforce diversity within business and management scholarship urgently requires a critical understanding of how the regime of inequality is produced and maintained in organizations.

Given the aforementioned background and general outlook, the aim of this paper is to carefully demonstrate the evolution of the notion of DM from past to present and highlight the key milestones that lay the foundation of the field of DM. This paper also scrutinizes how the idea of 'diversity' has been incorporated into the organisational agenda as well as reflects upon the critical debates on the meanings and ideological underpinnings attached to so-called 'being different' and 'being diverse'. By adopting a critical perspective, this paper not only addresses the business case for diversity on which the mainstream literature is based but also the complex and contested nature of equality and inclusiveness in the workplace by highlighting the contradictions and tensions inherent in various approaches which are largely influenced by societal, political and legal forces. Accordingly, the main research questions are as follows:

- What are the mainstream and critical debates/discussions, research streams and theoretical developments in diversity management (DM) research?

- How can critical, engaged and reflexive thinking contribute to the current understanding and conceptualisation of diversity scholarship?

In order to achieve the above mentioned aims and research questions, the remainder of this article is presented as follows: In the first section, we address the shift from equal employment opportunities to diversity management. In the second section, we highlight the main theoretical approaches for diversity management. In the third section, we compare and contrast diversity management versus the equal employment opportunity approach. In the fourth section, we discuss the managerial and organisational implications of diversity management by critically evaluating the 'business case for diversity'. Finally, we conclude our study with discussion and concluding remarks. Within this section, we also address the major challenges faced by the diversity scholarship and how to overcome these challenges by providing suggestions as well as directions for future research. 


\section{FROM EQUAL EMPLOYMENT OPPORTUNITIES TO DIVERSITY MANAGEMENT (DM)}

Historically, in the 19th and early 20th centuries, women and ethnic minorities were disadvantaged groups in terms of facing legal prohibitions against attaining advanced qualifications in the major professions, such as law and accountancy (Rees, 2006; Liff, 1997). Based on regulations such as the 1919 Sexual Disqualification (Removal) Act and the Sex Discrimination and Equal Payment Acts (1970) (Equality and Human Rights Commission, 2015), discrimination on the grounds of sex and ethnic identity was officially outlawed (Snell, 1979). Thus, regulations related to equality forced many organisations to create equal opportunities policies, especially in the UK. It was in this way that the organisations started calling themselves "equal opportunities employers." Having equal opportunities amongst employers led to the promotion of different approaches, such as DM (Kandola and Fullerton, 1994) and mainstreaming (Rees, 2006) by equal opportunities professionals (Lawrence, 2000). The concepts "DM" and "mainstreaming" have been used in order to link equal opportunity views in terms of establishing strategic organisational objectives. This bond created more awareness and helped others recognise diversity, not to mention it also promoting a broad equal opportunities agenda for both older workers and LGBTs (Lawrence, 2000).

Legal frameworks related to EEO approaches emphasise equal treatment irrespective of individuals' sex or ethnic origin. The main logic behind this notion is that of ensuring that individuals' sex or ethnic origin may not become a criterion for getting promoted, rewarded or appointed with respect to a job (Liff, 1997). It may be seen in some cases, however, that the principle of equally including any sex and race in occupations against indirect discrimination becomes breached because equal treatment may be unlawful if that treatment has an inordinate effect on the members of one sex or ethnic group. Such an unequal treatment can be legitimised if the criteria which create this difference can be indicated in a justifiable way on grounds different to that of sex or race (Liff, 1997).

The Equal Opportunities Approach (EOA) has mainly been criticised in terms of being outwardly effective and focusing especially women, the disabled, and ethnic minorities (Collins and Wray-Bliss, 2000; Liff, 1997; Kandola and Fullerton, 1994). The approach has widely tackled the moral considerations for social justice amongst different groups of employees. Kirton and Greene (2015), however, illustrate a contradiction and confusion 
regarding EOA by noting the distinction between the liberal approach (which focuses on social justice for the purpose of creating fair procedures which are the same for everyone) and the radical approach (which focuses on equally distributing rewards for the purpose of attaining an "equality of outcome") (Jewson and Mason, 1986). They do this because of the fact that both the liberal and radical approaches have been obscured because of a contradiction of approaches utilised in both public policy and organisational practice (Liff and Wajman, 1996; Bajawa and Woodall, 2006). Thus, diversity policies are proposed particularly in order to achieve organisational goals; in this respect, the concept of diversity is businessdriven rather than being social justice-oriented (Kaler, 2001). Based on this explanation of diversity policies, the main differences regarding EEO and DM can be summarised as follows: (i) the EEO uses moral or social justice cases and manages diversity by utilising an understanding of the business case, and (ii) EEO policies desire to achieve moral or social justice ends in practices; and this, in turn, is a benefit from a business's point-of-view. Diversity policies, however, have a more exclusive focus than EEO policies on the grounds of business cases (Kaler, 2001).

The historical development of the DM approach is a further step towards Equal Opportunities and was originally conceived in the United States (US) (Litvin et al., 2006; Litvin, 1997). The concept of diversity first arose in the publication of the Workforce 2000 Report in the US (Johnston and Packer, 1987) because it made some predictions regarding demographic changes and an increasingly diverse workforce in the world in an unfavourable way. Indeed, Litvin et al. (2006) states that the influence of those demographic predictions in the Workforce 2000 Report should not be overstated in the creation of a business case for diversity. Thus, organisations must face the challenges and threats of a diverse workforce; furthermore, they must also utilise that diverse workforce (Kirton and Greene, 2010). The benefits of having a diverse workforce have been cited as: developing a labour market advantage; a highly efficient employee potential; the conceiving of business opportunities; and an increase in creativity (Cornelius et al., 2001). DM studies gained its importance in Europe ten years after its conception in the USA. The introduction of DM was the same in Europe as in the USA (Holvino and Kamp, 2009). DM studies firstly came into force in the UK and then in the Netherlands (Wrench, 2008). Other European countries, on the other hand, adopted the concept of DM in the early 2000s (Boxenbaum, 2006).

Tatli (2011: 239) states that the current literature regarding DM is polarised between critical and mainstream logic. The difference between these approaches has evolved from 
their focal issues. Critical diversity studies consider group-based disadvantages (like issues of organisation), while, on the other hand, mainstream approaches consider performance-related outcomes of diversity. In Tatli's (2011: 241-243) critical study, she performed 19 semistructured interviews with diversity practitioners. The goal of this study was that of ascertaining the perceptions of professionals in accordance with organisational diversity policies and programmes. The diversity professionals were chosen from UK companies which have more than 10000 employees in different sectors. There are three important views which imply the importance of diversity and its management. Those are a) the utilisation of differences due to diversity; b) the logic of differences rather than equal opportunities; and c) the celebration of differences and managing them rather than the acceptance of sameness will be better than the adoption of equality logic.

Even if DM approach has a different perspective, including many advantages for realising and implementing this approach, some critiques have nevertheless been made against the DM approach (e.g. Humphries and Grice, 1995; Kersten, 2000). For instance, Kersten (2000) criticises DM as failing to give absolute prescriptions for the purpose of solving social concerns and surface-level issues. In addition to this criticism, discussions related to managing diversity have focused on the definitions and distinctions of the diversity concept (Mavin and Girling, 2000; Maxwell et al., 2003). The DM approach, however, was primarily formulated on the grounds of the business case. The business case for diversity has been introduced as incontestable. The reasons for making such a claim is because of the potential outcomes of this perspective. The outcomes of the business case perspective have been introduced with regards to the profit-based understanding in terms of hiring top talent employees, increasing creativity and innovation, and improving business flexibility and resilience in changing market conditions (Kandola and Fullerton, 1994; Gardenswartz and Rowe, 1998).

\section{THEORETICAL APPROACHES FOR DIVERSITY MANAGEMENT (DM)}

Diversity is a multinational concept (Singal and Gerde, 2015) which was also indicated in the Workforce 2000 Report (Johnston and Packer, 1987). The report creates multinational aspects of diversity by demonstrating demographic changes and increasing the diverse workforce throughout the world. Before the Workforce 2000 Report, diversity was recognised as being limited to racial, ethnic and gender identities. Nevertheless, diversity had other dimensions as well, including sexual orientation, religion, social class, physical ability, 
political affiliation and other personal affiliations. These were all paid increasing attention to after many diversity studies started focusing on those categories after the publication of the Workforce 2000 Report (Dreachslin, 2007; Baker et al., 2016; Windsor et al., 2015; Cox and Simpson, 2015; Nkomo and Hoobler, 2014). Diversity as a concept indicates differences among individuals. In order to use those differences efficiently, managing diversity has come to the fore. Therefore, in this section, we scrutinize theoretical approaches to DM by demonstrating their four main stages.

DM has been defined in many studies (Ivancevich and Gilbert, 2000; Sabharwal, 2014; Taylor, 2003; Charles, 2003; Gilbert et al., 1999). For example, the definition given by Ivancevich and Gilbert (2000: 75) is that of the "systematic and planned commitment by organizations to recruit, retain, reward, and promote a heterogeneous mix of employees." This definition of DM is a business case for diversity definition and was built up in four stages as Equal Employment Opportunity/Affirmative Action, Valuing Differences, DM and Global Diversity Management. In the first stage, we will discuss the proponents and critics of equal employment opportunities. In the second stage, we will examine valuing differences in order to demonstrate the transition to DM. In the third stage, we will inspect both the proponents and critics of DM; and in the last stage, we will introduce the global approach to DM. After introducing these stages, we will demonstrate different paradigms regarding DM in order to explore the concept more broadly.

\section{Stage One: Equal Employment Opportunity / Affirmative Action}

Obtaining the goals and objectives of the Civil Rights Movement was the leading reason why diversity theories and models gained popularity (Olzak and Ryo, 2007). For instance, the exclusion of African-Americans in the Constitution of US started to raise equality issues among US citizens. After the Constitution was changed in the interest of African-Americans, the state used affirmative action to increase the proportion of black women in the management level of diversity committees (Kalev et al., 2006). Also, some studies demonstrate that the striving to achieve equal rights based on legislation resulted in gaining these rights in terms of getting gender and ethnic equalities between the 1970s to 1987 (Konrad and Linnehan, 1995). Then, the Workforce 2000 Report opened up the second stage: that of valuing differences (Johnston and Packer, 1987). 
Stage Two: Valuing Differences

Awareness of diversity through the Workforce 2000 Report provided different approaches to the micro-, meso-, and macro-levels of society. The main argument for the micro-level was the individual theory which claims that organisations must consider the individual behaviour of employees at work, as well as their interactions with their colleagues. The argument at the meso-level claimed that organisations must adopt group theory. This encompasses recognising group behaviour, dynamics and development. The theory specifies that each group has a common sense of team-based work and experience-based learning, and valuing differences supports team-based outcomes (Johnson and Johnson, 2014). At the macro-level, multiculturalist arguments claim that differences among individuals are favourable because these differences increase the level of creativity, innovation, productivity and problem-solving in organisations (Cornelius et al., 2001; Kirton and Greene, 2010). After the valuing differences stage, the next stage is that of DM.

\section{Stage Three: Diversity Management}

Valuing differences was an important stage for the purpose of realising diversity and its benefits (Gilbert and Ivancevich, 2000). Awareness of diversity and valuing differences, however, were not enough to use them effectively; therefore, organisations needed to manage diversity in order to attain a culture of inclusion (Pless and Maak, 2004). In the literature, there are mainly three approaches regarding DM. The first approach comes from organisation theory. This theory highlights the importance of strategic frameworks and aligning diversity initiatives and programs. The main argument of this theory was approaching diversity as an asset for organisations. In the same vein, this theory claims that diversity provides organisational flexibility in responding to changes in business environments (McDonald, 2010). The second approach comes from the field of organisational change because organisational change management intertwines with DM. This is because organisational change needs to manage diversity strategically, not to mention obtaining a competitive advantage in the sector (Morrison et al., 2006; Ensari and Miller, 2006; Tatli, 2011). The last approach is the comprehensive model of DM. This model accepts diversity as a process rather than a formula because recognising diversity as a process will develop skills and positive approaches in terms of efficiency and effectiveness with regards to organisations which, in turn, provides uniqueness to the organisation. This means that diversity turns into the core 
competencies of organisations which cannot be copied by other organisations (Ollapally and Bhatnagar, 2009).

\section{Stage Four: Global Diversity Management}

Theories in Global Diversity Management (hereafter GDM) emphasise the importance of management functions; these include the planning, coordination and implementation of strategies for the purpose of having organisations grow in terms of international, global and transnational levels (McDonald, 2010). Thus, GDM can be defined as the "planning, coordination and implementation of a set of management strategies, policies, initiatives and training and development activities that seek to accommodate diverse sets of social and individual backgrounds, interests, beliefs, values and ways of work in organizations with international, multinational, global and transnational workforces and operations" (Ozbilgin and Tatli, 2008: 8). Nishii and Ozbilgin (2007) mention two primary issues regarding GDM. The first regards the changing social, legal and political perspectives of how to define DM across countries. This indicates that DM programmes may be inappropriate due to the contextual differences of cultures and that GDM raises issues regarding how multicultural teams in global companies can be managed and how effective communication and interactions can be provided amongst global employees and units.

The stages that are indicated above are processes regarding how the concept of DM turns into that of a necessity for organisations. In what follows, we will scrutinise the fundamental paradigms which are related to DM. Based on the studies conducted by Thomas and Ely (1996), three well-observed paradigms were explained in terms of DM; the starting level (the discrimination and fairness paradigm), the initial level (the access and legitimacy paradigm), and the strategic level (the learning and effectiveness paradigm). These paradigms indicate different purposes of DM, and any organisation may be typified as embodying one of these paradigms. In order to explore the differences between the various approaches to DM, we will discuss these paradigms separately.

Firstly, discrimination and fairness paradigm consider compliance and reactive responses to diversity issues. Moral and legal imperatives are the main drives for this paradigm, with the central issue of that paradigm being anti-discrimination. The paradigm is one of the ways one may understand diversity. As a lens, it includes the concepts of equal opportunity, fair treatment to employees, and recruitment without considering any diverse feature and obedience to federal Equal Employment Opportunity requirements. The positive 
side of this paradigm is to take into consideration diversity as the richest part of an organisation in order to increase its effectiveness (Thomas and Ely, 1996; Gilbert et al., 1999). The main limitation of this paradigm, however, is that of adopting the notion of sameness rather than differences. This, in turn, means that all employees are similar with regards to organisational work and culture (Thomas and Ely, 1996). Actually, this paradigm discriminates against diversity because it ignores the fact that diversity is a source of discrimination. In the study conducted by Thomas and Ely (1996), the case of Iversen Durham, an international consulting firm, is an indicator of the weakness of the paradigm. In this case, after Iverson created racial and gender diversity in order to reach higher effectiveness, some organisational members accused Ivensen because of its discriminating with regards to race. The result of this research indicates that adopting the discrimination and fairness paradigm creates blindness because the logic of sameness caused the organisation not to notice that it was discriminating along racial lines.

Secondly, the access and legitimacy paradigm is a "positive action" form of diversity interventions. The business case for diversity is the basic argument used in defence of this paradigm. It is limited, however, because it focuses on initiatives for improving access to marginalised groups and individuals. The main purpose of this paradigm is to access niche markets. Thomas and Ely (1996:5) argue for this paradigm as follows:

We are living in an increasingly multicultural country, and new ethnic groups are quickly gaining customer power. Our company needs a demographically more diverse workforce to help us gain access to these differentiated segments. We need employees with multilingual skills in order to understand and serve our customers better and to gain legitimacy with them. Diversity isn't just fair, it makes business sense. (Thomas and Ely, 1996: 5)

This paradigm also has some strengths and weaknesses. Its strengths include having a market-based motivation and that it creates a competitive advantage due to its accepting diversity amongst customers, clients, and the labour pool. This paradigm's weakness is that, even though it emphasises the importance of cultural differences, it does not allow for one to understand how the differences can affect the work that is done (Thomas and Ely, 1996; Gilbert et al., 1999).

Thirdly, the learning and effectiveness paradigm considers diversity in terms of the organisation's journey towards learning and continues improving itself. It is usually driven by 
the recognition that leveraging internal and external diversity is an essential competence for a healthy organisation which pursues excellence as part of its overall culture.

The theories and approaches regarding DM have provided an understanding of the concept. Till now, however, we mostly explored diversity and DM within their relevant aspects. Now we shall turn to make a distinction between DM and equal opportunities in order to understand those concepts separately. Thus, in the next section, we will mainly discuss the differences between the equal opportunity approach and the DM approach.

\section{THE DIVERSITY MANAGEMENT (DM) VERSUS THE EQUAL EMPLOYMENT OPPORTUNITY APPROACH}

The understanding of diversity management has changed with regards to the US and UK (non-US) models (Lorbiecki and Jack, 2000). Thus, in this section, we will scrutinise the differences between DM and EEO. These differences will provide an understanding regarding the needs for a transition from EEO to DM.

Based on the research of Kandola and Fullerton (1994), Kirton and Greene (2010: 251) have created a typology of five main differences between DM and EO: (a) principles, (b) focus, (c) methods, (d) implementations, and (e) policy levers.

The first difference between the two approaches is that of principles. EEO provides rights for discriminated people based on legislation and ensures that no unlawful discrimination will be committed. DM, on the other hand, considers diversity's benefits to business and, in order to maximise the potential contribution of employees to businesses, it considers valuing people in terms of a profit-oriented ethos. The second difference is that of focus. EEO focuses on women, minority ethnicities, and disabled people (Hoque and Noon, 2004); therefore, it is group-focused rather than individual-focused. This provides a dismissive approach to other diversities such as sexual orientation and religion. DM, however, has an individual focus and considers any people who belong to any type of minority or class. The third difference between the two approaches is in regard to methods. EEO and DM have different methodological approaches. Whereas EEO emphasises such procedures as recruitment and selection, DM emphasises internal culture change. The fourth difference is that of implementation. For DM, managers are responsible for managing diversity. Even this seems like an attractive ideal, this can create problems regarding women because, if managers adopt the notion that gender equality does not have any importance on business outcomes, 
they might not provide gender equality in organisations (Maxwell et al., 2001). Therefore, gender equality has been provided by legislation in order to protect the rights of women. EEO, on the other hand, implements itself via legislation. This, however, may create subtle discrimination for women (Bayer and Squire, 2014). And the fifth difference between the two approaches is its policies. There is one main difference regarding the policies which EEO and DM adopt. EEO adopts the policy of "positive (affirmative) action for recruiting, developing and promoting underrepresented groups however, DM considers individual competencies as the basis of recruitment, development and promotion" (Kirton and Greene, 2010: 251).

Based on the results of a survey conducted with 160 federal agencies, Kellough and Naff (2004) summarise the differences amongst those two concepts in Table 1.

Table 1. EEO versus DM

\begin{tabular}{ll}
\hline \multicolumn{1}{c}{ EEO / AA } & \multicolumn{1}{c}{ Diversity Management } \\
\hline Mandatory & Voluntary \\
Legal, social, moral justification & Productivity, efficiency, and quality \\
Focuses on race, gender and ethnicity & Focuses on all elements of diversity \\
Changes the mix of people & Changes the system/operations \\
Perception of preference & Perception of equality \\
Short term and limited & Long term and ongoing \\
Grounded in assimilation & Grounded in individuality \\
\hline
\end{tabular}

Source: Kellough and Naff (2004: 65) 
Table 2. Comparison Between EEO and Diversity Management (idealized)

Equal Employment Opportunities

Diversity Management

Programs derive from legal frameworks Programs depend on organisational initiative, organisationa outlawing discrimination. Positive action culture.

Externally driven

Confrontational at times

Equality through sameness, merit-based.

Driven by legal compliance, target compliance and moral responsibility

Aims to increase the proportion of minorities. Tracking movements of disadvantaged groups. Particular focus on gender and ethnicity.

Operational concern, especially involving HR function and focusing on formal processes.

Primarily group perspective. Sees the workforce as collective.

Concentrates on issues of discrimination, correcting injustice and redressing past wrongs. Focus on power and oppression.
Internally driven, proactive

Voluntary self-interest

Contribution through uniqueness.

Business case and commercial objectives linked to rationale.

Aims to increase the inclusion of people with unique characteristics. Moving beyond statistics; valuing differences and benefits. Maximizing the potential of all employees.

Strategic concern. All managers involved, especially line managers and upper management levels.

About groups as well as individuals.

Mosaic result: Equality through differences. Both organisations and employees can benefit.

Source: Jonsen, Maznevski and Schneider (2011: 40)

As seen in Table 1 and Table 2, EEO comes from the legislative protection of individuals because it is mandatory and based on legal, social and moral justifications. EEO has a more group focus. DM, on the other hand, is voluntarily-based and more individual centred. The main difference between those two concepts is to understand groups who face discrimination. EEO/AA focuses on discrimination based on race, gender and ethnicity; however, DM encompasses a larger list of diversities, including sexual orientation, religion and culture, in addition to race, gender and ethnicity. For some scholars (Jonsen et al., 2011), there are crucial differences between EEO and DM approaches. Accordingly, they argue that EEO and DM compete for each other. On the contrary, some scholars (Özbilgin and Tatli, 2008) view these two concepts as complementary rather than contradictory. Given the fact that the ideological positioning of these two approaches varies substantially, the major beneficiaries of DM approach are usually the private sector, whereas the main beneficiaries of EEO approach are the trade unions and critical management scholars (Özbilgin and Tatli, 2008). 


\section{MANAGERIAL AND ORGANISATIONAL IMPLICATIONS}

Given the increasingly heterogeneous profile of today's and more likely the future's workforce in terms of sex, race, ethnicity, disability, belief or religion, age, sexual orientation and gender identity, there are certain challenges as well as opportunities managers and HR practitioners are waiting for. First of all, the decision makers in organisations should consider how organisational objectives can be translated effectively into certain diversity policies. Second, they should be aware of how they can measure and monitor their diversity goals and outcomes as well as how predetermined diversity policies are put into practice within their organisations. Third, it is crucial to set the appropriate ground for the 'business case' for diversity from the viewpoint of managerial interests and expectations. Indeed, this is in line with the evidence largely put forward by the North American dominated scholarship and managerial discourse of diversity which relies heavily on the assumptions of the business case for diversity to enhance the organisational effectiveness. On the other hand, the arguments on the basis of legal, ethical reasoning, social justice and corporate social responsibility also coexist along with arguments for the business case. In line with this opposing view of the business case for diversity, Noon (2007: 778) raises a critical point with regards to the "fatal flaws of the business case for diversity by arguing that "if the business case for diversity were so compelling, why are not all firms adopting it?" There are possible explanations behind the reluctance or unwillingness of firms in adopting the business case for diversity arguments. Some organisations tend to see the quick results and benefits of the diversity management programs that cannot be easily measured or observed in the short run. Moreover, there is actually mixed and somewhat contradictory research evidence on the business case for diversity whether it necessarily results in favourable performance outcomes for organisations (Özbilgin and Tatli, 2011). In this regard, the role of context in shaping the organisational diversity policies and programs should not be underestimated. Some cultures express diversity as corporate social responsibility or adopt social justice and ethical perspective rather than in terms of dollar generated at the end of the day. For example, in Japanese culture, organisations are more likely to pursue a corporate social responsibility approach as a reasoning or justification for diversity instead of business case or competitiveness (Özbilgin and Tatli, 2008). 


\section{Discussion and Concluding Remarks}

The mainstream literature to a great extent has focused on the discussion of DM practices on multinational, global firms with a high emphasis on employment relations and workforce composition in the private sector. Yet, it has not been a subject of in-depth examination, except for a couple of studies (Bridgstock vd., 2010; Woodhams ve Lupton, 2006a, 2006b), within the context of the third sector, voluntary organizations, and social entrepreneurship. Critical management scholars (Zanoni ve Janssens, 2003; 2007; Zanoni, 2011) argue that not regarding and giving credit to but exploiting workforce diversity lies behind the conception covered in the mainstream diversity literature that is dominated by the pro-managerial perspective. Accordingly, having reviewed the extant diversity literature, the following specific issues, research challenges and insights into diversity management can be identified: First, as an extension of the neo-liberal discourse, organizational differences are reduced to the individual level; collective and group interest are pushed into the background; and structures of power, class relations and inequality are largely ignored. Making a holistic analysis of diversity management, Özbilgin and Tatli (2011) stress that individualism has taken precedence over collectivism. Second, studies taking an 'etic' perspective with a promanagerial rhetoric evaluate the phenomenon of diversity largely based on organizational performance and outputs but neglect social equality, social justice, and moral values (Noon, 2007). In this way, to the contrary of how it is idealized, diversity management turns into a managerial instrument and discourse used by the management to attain their own goals, legitimize their own practices rather than ensuring workplace equality and inclusion in a true sense.

Diversity research itself is not 'diverse' (Jonsen et al., 2011). The literature on diversity management has a predominant focus on North American centric research paradigm. Despite the fact that diversity research is to large extent context dependent and specific, most of the existing research has been carried out in the western world, particularly within the Anglo-Saxon context. Yet, we know very little about the emerging issues in other contexts which are under-represented in the mainstream literature. Therefore, diversity scholars are highly suggested to adopt an intersectional approach (multiple categories of diversity) rather than utilizing single categories of diversity and to go beyond the already studied contexts by choosing samples which are usually difficult to access. They should also become aware of 'diversity within diversity' while investigating the target population. For instance, it will be misleading to assume that all LGBTI individuals behave in a certain way or direction without 
taking into account the considerable ethnic, social or economic class differences, heterogeneity within the same community.

The relevant question might not only be "how context matters" in diversity management research but also "how context matters in terms of power" and "how context matters as a component of power relations in the production of diversity knowledge". Focusing merely on a particular socio-cultural and historical context surrounding an organisation by neglecting the established power relations and systemic sources of disadvantage has been so widespread in the mainstream research that power and context simultaneously have not been adequately conceptualized and operationalized into research practice in the field (Ahonen et al., 2014). Indeed, to a large extent power relations are invisible and context is hidden within the mainstream framework of diversity management studies (as such an example see Joshi and Roh, 2009) which relied heavily on a positivist epistemology. Knowing that power and context are highly intertwined rather than being two separate entities, the relations between power and context should be further analyzed and questioned by the critical scholars in seeking to account the inclusionary and exclusionary practices of organizations against minority individuals. Given the fact that the there are noteworthy differences among different contexts (such as sector, industry, country, region or occupation), diversity scholars should carefully approach the each context by taking into account the specific contextual characteristics where several other diversity categories (such as race, ethnicity and social class) come into play (Day \& Greene, 2008). In relation to race, gender and class as interacting processes of identity, Acker (2006) put forward the regimes of inequality as organizing processes that produce patterns of complex inequalities.

As can be seen from the above discussion that one of the important, yet neglected, underutilized approaches to studying diversity in the workplace rely on intersectionality research. Even though the significance of intersectionality for the several areas (gender, race, ethnicity, class etc.) in diversity management field has already been mentioned by a number of scholars previously (Holvino, 2010; Phoenix and Pattynama, 2006; McCall, 2005; Adib and Guerrier, 2003), there are relatively few empirical researches adopting the intersectional approach. Let us consider the debate of whether lesbian women experience an advantage in non-traditionally female work compared to heterosexual women. We can argue that some authors (see for instance Wright, 2011) are very critical and cautious about to make a clearcut explanation that there is a "lesbian advantage" over heterosexual women in maledominated work since other intersecting variables such as class differences and ethnicity 
come into play, differentiate the experiences of lesbians at work. Thus, the extent to which lesbians gain greater advantages at work is far complex and contradictory and it might be influenced by a number of dimensions concerning class, ethnicity as well as organisational culture, practices and response (Wright, 2011). The article by Taylor (2007) examined indepth the working class lesbians' views and experiences of commercialized scene space in England to highlight inequalities to produce a gendered, classed and sexualized sense of inclusion or exclusion. Regarding the working class lesbians in seeking to access lesbian and gay scene space, Taylor (2007) raised strong criticisms against scene space as being "pretentious", "middle-class", "male" and what Casey (2004) called the "de-dyking" of queer space with the following phrases: 'if your face doesn't fit, you're not getting in'. In an ethnographic study to investigate the class dynamics embedded in daily and routine actions and behaviours of employees and managers in a work environment dominated by male workers, Embrick et al., (2007) underlined that white working class men constructed and maintained white male solidarity as a collective practice against homosexuals. Thus, the above-stated discussion demonstrates that further research is necessary to shed light on the complex interactions among multiple group identities in organisations and the impact of these intersectional identities on employees’ workplace experiences (Ragins et al., 2003: 71).

Meanwhile, while some aspects of diversity have become relatively more 'visible' and 'acceptable' in the modern world, some other aspects of diversity (such as sexual orientation and LGBTI diversity) have still remained invisible at work as well as in academia and deserve greater scholarly investigation. As Shore et al., (2009) argued, further research should be carried out to investigate sexual orientation from an inclusiveness perspective. For example, exploring interpersonal relationships and workplace friendships (Rumens, 2012; 2010; 2008) within the workgroups of sexual minorities across various contexts are one of the most influential and challenging areas of research that have received scant attention by far in scholarly studies. 


\section{REFERENCES}

Acker, J. (2006), “Inequality regimes: Gender, class and race in organizations”, Gender \& Society, 20(4), $441-464$.

Adib, A. and Guerrier, Y. (2003), "The Interlocking of Gender with Nationality, Race, Ethnicity and Class: The Narratives of Women in Hotel Work", Gender Work and Organization 10(4), 413-32.

Ahonen, P., Tienari, J., Meriläinen, S. and Pullen, A. (2014), "Hidden contexts and invisible power relations: A Foucauldian reading of diversity research". Human Relations, 67(3), 263-286

Bajawa, A. and Woodall, J. (2006), "Equal opportunity and diversity management meet downsizing: a case study in the UK airline industry", Employee Relations, 28(1), 46-61.

Baker, D.L., Schmaling, K., Fountain, K.C., Blume, A.W. and Boose, R. (2016), "Defining diversity: A mixed method analysis of terminology in faculty applications", The Social Science Journal, 53(1), 60-66.

Boxenbaum, E. (2006), "Lost in translation the making of danish diversity management", American Behavioral Scientist, 49(7), 939-948.

Bridgstock, R., Lettice, F., Ozbilgin, M.F. and Tatli, A. (2010), "Diversity management for innovation in social enterprises in the UK. Entrepreneurship \& Regional Development", 22 (5), 1-18.

Casey, M. (2004), "De-dyking queer space(s): heterosexual female visibility in gay and lesbian spaces", Sexualities, 7(4), 446-461.

Charles, J. (2003), "Diversity management: An exploratory assessment of minority group representation in state government", Public Personnel Management, 32(4), 561-577.

Collins, H. and Wray-Bliss, E. (2000), "Equal Opportunities Policies: The Authority of Discrimination”, Management Research News, 23(9/10/11), 39-41.

Cornelius, N., Gooch, L. and Todd, S. (2001), "Managing difference fairly: an integrated 'partnership'approach", in Noon, M. and Ogbonna, E. (eds.) Equality, diversity and disadvantage in employment. Basingstoke: Palgrave, pp. 32-50.

Cox, L.G. and Simpson, A. (2015), "Cultural safety, diversity and the servicer user and carer movement in mental health research", Nursing inquiry, 22(4), 306-316.

Day, N. E. and Greene, P. G. (2008), "A case for sexual orientation diversity in small and large organizations". Human Resource Management, 47(3), 637-654.

Dreachslin, J.L. (2007), "Diversity management and cultural competence: Research, practice, and the business case", Journal of Healthcare Management, 52(2), 79-86.

Embrick, D. G., Walther, C. S. and Wickens, C. M. (2007), "Working class masculinity: Keeping gay men and lesbians out of the workplace", Sex Roles, 56(11-12), 757-766.

Ensari, N.K. and Miller, N. (2006), "The application of the personalization model in diversity management", Group Processes \& Intergroup Relations, 9(4), 589-607.

Gardenswartz, L. and Rowe, A. (1998), "Why diversity matters”, Hr Focus, 75(7),1-3.

Gilbert, J.A. and Ivancevich, J.M. (2000), "Valuing diversity: A tale of two organizations", The Academy of Management Executive, 14(1), 93-105.

Gilbert, J.A., Stead, B.A. and Ivancevich, J.M. (1999), “Diversity management: A new organizational paradigm”, Journal of Business Ethics, 21(1), 61-76.

Holvino, E. (2010), "Intersections: the simultaneity of race, gender and class in organization studies", Gender, Work \& Organization, 17(3), 248-277.

Holvino, E. and Kamp, A. (2009), 'Diversity management: Are we moving in the right direction? Reflections from both sides of the North Atlantic', Scandinavian Journal of Management, 25(4), 395-403.

Hoque, K. and Noon, M. (2004), "Equal opportunities policy and practice in Britain: evaluating the 'empty shell'hypothesis", Work, Employment \& Society, 18(3), 481-506.

Humphries, M. and Grice, S. (1995), "Equal employment opportunity and the management of diversity: a global discourse of assimilation?", Journal of Organizational Change Management, 8(5), 17-32. 
Jewson, N. and Mason, D. (1986), "The theory and practice of equal opportunities policies: liberal and radical approaches", The Sociological review, 34(2), 307-334.

Johnson, D.W. and Johnson, F.P. (2014), Joining together: Group theory and group skills . 11th edn. UK: Prentice-Hall, Inc.

Johnston, W.B. and Packer, A.E. (1987), Workforce 2000: Work and workers for the twenty-first century. Indianapolis: DIANE Publishing.

Jonsen, K., Maznevski, M. L. and Schneider, S. C. (2011), "Special Review Article: Diversity and its not so diverse literature: An international perspective", International Journal of Cross Cultural Management, 11(1), 35 -62.

Joshi, A. and Roh, H. (2009), "The role of context in work team diversity research: A meta-analytic review". Academy of Management Journal, 52(3), 599-627.

Kaler, J. (2001), “Diversity, equality, morality”, in Noon, M. and Ogbonna, E. (eds.) Equality, diversity and disadvantage in employment. Basingstoke: Palgrave, pp. 51-64.

Kalev, A., Dobbin, F. and Kelly, E. (2006), "Best practices or best guesses? Assessing the efficacy of corporate affirmative action and diversity policies", American Sociological Review, 71(4), 589-617.

Kandola, R.S. and Fullerton, J. (1994), Managing the mosaic: Diversity in action. Institute of Personnel and Development.

Kellough, J. E. and Naff, K. C. (2004), "Managing diversity in the federal service: Responding to a wake-up call". Administration \& Society, 36(1), 62-90.

Kersten, A. (2000), "Diversity management: Dialogue, dialectics and diversion”, Journal of Organizational Change Management, 13(3), 235-248.

Kirton, G. and Greene, A. (2010), “'What does diversity management mean for the gender equality project in the United Kingdom? Views and experiences of organizational "actors", Canadian Journal of Administrative Sciences/Revue Canadienne des Sciences de l'Administration, 27(3), 249-262.

Kirton, G. and Greene, A. (2015), The dynamics of managing diversity: A critical approach. Routledge.

Konrad, A.M. and Linnehan, F. (1995), "Formalized HRM structures: coordinating equal employment opportunity or concealing organizational practices?", Academy of Management Journal, 38(3), 787-820.

Lawrence, E. (2000), “Equal opportunities officers and managing equality changes”, Personnel Review, 29(3), $381-402$.

Liff, S. (1997), "Two routes to managing diversity: individual differences or social group characteristics", Employee Relations, 19(1), 11-26.

Liff, S. and Wajcman, J. (1996) 'Sameness' and 'difference'revisited: which way forward for equal opportunity initiatives?', Journal of Management Studies, 33(1), 79-94.

Litvin, D.R. (1997), “The discourse of diversity: From biology to management”, Organization, 4(2), 187-209.

Litvin, D.R., Konrad, A. and Pringle, J. (2006), "Making space for a better case", in Prasad, P., Prongle, J. And Konrad, A. (eds.) Handbook of Workplace Diversity. London: Sage, pp. 75-94.

Lorbiecki, A. and Jack, G. (2000), "Critical turns in the evolution of diversity management", British Journal of Management, 11(1), 17-31.

Mavin, S. and Girling, G. (2000), "What is managing diversity and why does it matter?", Human Resource Development International, 3(4), 419-433.

Maxwell, G. A., Blair, S., and McDougall, M. (2001), "Edging towards managing diversity in practice”. Employee relations, 23(5), 468-482.

Maxwell, G., McDougall, M., Blair, S. and Masson, M. (2003), "Equality at work in UK public-service and hotel organizations: inclining towards managing diversity?", Human Resource Development International, 6(2), 243258.

McCall, L. (2005), “The Complexities of Intersectionality”, Signs, 30(3), 1771-800.

McDermott, E. (2006). "Surviving in dangerous places: lesbian identity performances in the workplace, social class and psychological health", Feminism \& Psychology, 16(2), 193-211.

McDonald, D.M. (2010), "The Evolution of 'Diversity Management'in the USA: Social Contexts, Managerial Motives and Theoretical Approaches", Institute of Business Research, Daito Bunka University. 
Morrison, M., Lumby, J. and Sood, K. (2006), "Diversity and diversity management messages from recent research", Educational Management Administration \& Leadership, 34(3), 277-295.

Nishii, L.H. and Özbilgin, M.F. (2007), "Global diversity management: towards a conceptual framework", The International Journal of Human Resource Management, 18(11), 1883-1894.

Nkomo, S. and Hoobler, J.M. (2014), “A historical perspective on diversity ideologies in the United States: Reflections on human resource management research and practice", Human Resource Management Review, 24(3), 245-257.

Noon, M. (2007), “The fatal flaws of diversity and the business case for ethnic minorities". Work, employment and society, 21(4), 773-784.

Ollapally, A. and Bhatnagar, J. (2009), “The holistic approach to diversity management: HR implications', Indian Journal of Industrial Relations”, 454-472.

Olzak, S. and Ryo, E. (2007), "Organizational diversity, vitality and outcomes in the civil rights movement", Social Forces, 85(4), 1561-1591.

Ozbilgin, M. (2008), “Global Diversity Management”, in Smith, P.B., Peterson, M.F. and Thomas, D.C. (eds.) The Handbook of Cross Cultural Management Research. Thousand Oaks: SAGE.

Özbilgin M and Tatli A (2008), “Global Diversity Management: An Evidence-Based Approach”. Basingstoke and New York: Palgrave Macmillan.

Özbilgin, M., and Tatli, A. (2011), "Mapping out the field of equality and diversity: Rise of individualism and voluntarism”. Human Relations, 64(9), 1229-1253.

Phoenix, A. and Pattynama, P. (2006), “Editorial: Intersectionality”, European Journal of Women’s Studies, 13(3), 18792.

Pless, N. and Maak, T. (2004), "Building an inclusive diversity culture: Principles, processes and practice", Journal of Business Ethics, 54(2), 129-147.

Ragins, B. R., Cornwell, J. M. and Miller, J. S. (2003), "Heterosexism in the Workplace: Do Race And Gender Matter?", Group \& Organization Management, 28, 45-74.

Rees, T. (2006), "Mainstreaming equality in the European Union”. Routledge.

Rumens, N. (2012), “Queering cross-sex friendships: An analysis of gay and bisexual men's workplace friendships with heterosexual women", Human Relations, 65(8), 955-978.

Rumens, N. (2010), "Firm friends: exploring the supportive components in gay men's workplace friendships", The Sociological Review, 58(1), 135-155.

Rumens, N. (2008), “Working at intimacy: gay men's workplace friendships”. Gender, Work \& Organization, 15(1), 930.

Sabharwal, M. (2014), "Is diversity management sufficient? Organizational inclusion to further performance”, Public Personnel Management, 43(2), 197-217.

Schwindt-Bayer, L. and Squire, P. (2014), “Legislative Power and Women's Representation”, Politics \& Gender, 10(4), 622-658

Shore, L. M., Chung-Herrera, B. G., Dean, M. A., Ehrhart, K. H., Jung, D. I., Randel, A. E., and Singh, G. (2009), "Diversity in organizations: where are we now and where are we going?", Human Resource Management Review, 19(2), 117-133.

Singal, M. and Gerde, V.W. (2015), “Is Diversity Management Related to Financial Performance in Family Firms?”, Family Business Review, 28(3), 243-259.

Snell, M. (1979), "The Equal Pay and Sex Discrimination Acts: their impact in the workplace”, Feminist Review, 1(1), 37-57.

Tatli, A. (2011), A multi-layered exploration of the diversity management field: diversity discourses, practices and practitioners in the UK", British Journal of Management, 22(2), 238-253.

Taylor, Y. (2007), "If Your Face Doesn't Fit...: The Misrecognition of Working-Class Lesbians in Scene Space”. Leisure Studies, 26(2), 161-178.

Taylor, T. (2003), "Diversity management in a multi-cultural society: An exploratory study of cultural diversity and team sport in Australia", Annals of Leisure Research, 6(2), 168-188. 
Thomas, D.A. and Ely, R.J. (1996), "Making differences matter: A new paradigm for managing diversity", Harvard Business Review, 74(5), 79-90.

Windsor, L.C., Shorkey, C. and Battle, D. (2015), "Measuring student learning in social justice courses: The diversity and oppression scale", Journal of Social Work Education, 51(1), 58-71.

Woodhams, C. and Lupton, B. (2006a), “Gender-based equal opportunities policy and practice in small firms: The impact of HR professionals”. Human Resource Management Journal. 16(1), 74-97.

Woodhams, C. and Lupton, B. (2006b), "Does size matter? Gender-based equal opportunity in UK small and medium enterprises". Women in Management Review, 21(2), 143-69.

Wrench, J. (2008), "Diversity management and discrimination: Immigrants and ethnic minorities in the EU", Human Resource Management International Digest, 16(4).

Wright, T. (2011), “A "lesbian advantage? Analysing the intersections of gender, sexuality and class in male dominated work”, Equality, Diversity and Inclusion: An International Journal, 30(8), 686-701.

Zanoni, P. and Janssens, M. (2003), “Deconstructing Difference: The Rhetoric of Human Resource Managers' Diversity Discourses", Organization Studies. 25(1), 55- 74.

Zanoni, P. and Janssens, M. (2007), "Minority Employees Engaging with (Diversity) Management: An Analysis of Control, Agency and Micro-Emancipation”, Journal of Management Studies, 44(8), 1371-97.

Zanoni, P. (2011). "Diversity in the lean automobile factory: doing class through gender, disability and age", Organization. 18(1), 105-127. 